\title{
PELAKSANAAN DIVERSI DALAM PENYELESAIAN PERKARA ANAK YANG BERHADAPAN DENGAN HUKUM DI POLRES SIJUNJUNG*
}

\author{
*Sry Wahyuni, Helfira Citra \\ Universitas Dharma Andalas, Jln Sawahan No 103A Simpang Haru Padang \\ "e-mail: Sryunidha@gmail.com, \\ e-mail: helfirarizkya@yahoo.com
}

\begin{abstract}
This Research discuss diversion implementation by the police station of Sijunjung as the alternatif resolving criminal case children in conflict with law. As for that to be special purpose from this research: the first, describe the diversion implementattion as the alternatif resolving criminal case children in conflict with law; the second, Describe the from of diversion as mediation penal that implementation in Sijunjung Police station; the third Conclude any obstacles faced in diversion implementation as the alternatif resolving criminal case children in conflict with law of Sijunjung Police station. The result of this research is implementation of diversion can be more optimal. In case to solve the problem of children especially child crime for guarantee legal certanty for children in conflict with law. This process usually settle out of court, that is through diversion based on approach restorative justice in the Sijunjung region. Therefore, not many children are required carry out criminal liability that should in the age of children get contruction according to their age.
\end{abstract}

Keywords: Diversion, Children, Dealing With Law

\begin{abstract}
Abstrak
Penelitian ini membahas pelaksanaan diversi oleh kepolisian Sijunjung sebagai alternatif penyelesaian perkara terhadap anak yang berhadapan dengan hukum. Adapun yang menjadi tujuan khusus dari penelitian ini : Pertama, Mendeskripsikan pelaksanaan diversi sebagai alternatif penyelesaian perkara terhadap anak yang berhadapan dengan hukum; kedua, Menjelaskan bentuk diversi sebagai mediasi penal yang diterapkan Polres Sijunjung; ketiga, Menyimpulkan kendala apa saja yang dihadapi dalam pelaksanaan diversi sebagai alternatif penyelesaian perkara terhadap anak yang berhadapan dengan hukum di Polres Sijunjung. Penelitian ini dilakukan di Polres Sijunjung dengan segala konteksnya sesuai dengan informasi yang ingin didapatkan. Hasil akhir yang dapat diwujudkan dari penelitian ini adalah implementasi diversi yang lebih optimal. Dalam upaya penyelesaian perkara terhadap anak, khususnya tindak pidana anak untuk jaminan kepastian hukum bagi anak yang berhadapan dengan hukum. Proses ini biasanya dilakukan di luar jalur pengadilan, yakni melalui diversi berdasarkan pendekatan keadilan restoratif di wilayah Sijunjung. Sehingga tidak banyak anak yang diwajibkan untuk melakukan pertanggungjawaban pidana yang seharusnya di usia anak-anak itu mendapatkan pembinaan sesuai umurnya.
\end{abstract}

Kata Kunci: Diversi, Anak, Berhadapan Dengan Hukum.

\footnotetext{
* Naskah diterima: 09 Agustus 2018, direvisi: 24 Agustus 2018, disetujui untuk terbit: 25 September 2018
} 


\section{PENDAHULUAN}

Anak tumbuh dan berkembang dalam kehidupannya tidak bisa terlepas dari pengaruh sosial maupun lingkungan dimana tinggal tumbuh dan berkembang. Pengaruh lingkungan itu bisa saja mulai dari hal yang positif sampai ke hal yang negatif sekalipun, secara alamiahnya anak dalam proses perkembangan memiliki kecenderungan rasa ingin tahu yang lebih tinggi Lingkungan yang jahat membuat anak menjadi jahat. Hal ini membuat kita seringkali menemukan ada banyak anak yang tersangkut dalam masalah hukum ataupun berhadapan dengan hukum, baik itu anak sebagai korban tindak pidana khusnya anak sebagai pelaku tindak pidana.

Meningkatnya kenakalan-kenakalan anak setiap tahunnya, baik dari segi kualitas maupun modus operandi yang dilakukan. Tidak jarang juga perbuatan yang dilakukan oleh anak tersebut sudah meresahkan semua pihak. Fenomena meningkatnya pola perilaku tindak pidana yang dilakukan oleh ana ini, seolah-olah tidak berbanding lurus dengan usia pelaku. Selain itu, berbagai cara dilakukan dalam pencegahan dan penanggulangan kenakalan anak, perlu segera dilakukan (Sambas, Nandang, 2010: 103). Bagi anak yang berhadapan dengan hukum maka anak harus mendapatkan perlindungan labelisasi dan anak yang berhadapan dengan hukum berhak mendapatkan rehabilitasi (Undangundang Perlindungan Anak No. 35 Tahun 2014).
Secara garis besarnya lingkungan sosial mengatakan mutlak bagi seseorang yang telah melakukan suatu kejahatan atau tindak pidana dapat mempertanggungkan atas perbuatan yang telah dilakukan tanpa terkecuali pelakunya adalah anak. Hal yang demikian menjadi tuntutan agar dapat memberikan efek jera bagi anak pelaku, agar untuk ke depannya tidak akan mengulangi atau melakukan kejahatan yang sama. Sistem hukuman yang diterapkan kepada anak harus melihat faktor perkembangan dan mentalitas bagi anak serta kepentingan yang paling menguntungkan bagi anak. Anak sebagai pelaku tindak pidana wajib mendapatkan perlindungan dan perhatian untuk hakhaknya maka perkembangan mental anak di masa pertumbuhannya tidak akan terganggu dengan masalah yang sedang dihadapi. Maka dari itulah yang mendasar untuk diwujudkannya sistem peradilan anak.

Tujuan sistem peradilan pidana anak yaitu memajukan kesejahteraan anak dan memperhatikan prinsip proporsionalitas. Yang mana tujuan proporsionalitas itu mengekang penggunaan sanksi-sanksi, yang kebanyakan dinyatakan dalam batasan-batasan ganjaran yang setimpal dengan beratnya pelanggaran hukum. Tetapi juga memperhatikan pada pertimbangan keadaan-keadaan pribadinya (Wahyudi Setia, 2011: 2). Dalam Undang-Undang Nomor 35 Tahun 2014 tentang Perubahan Atas UndangUndang Nomor 23 Tahun 2002 tentang Perlindungan Anak memberikan 
Sry Wahyuni dan Helfira Citra: Pelaksanaan Diversi Dalam Penyelesaian Perkara Anak...

pengaturan yang jelas dan komprehensif tentang perlindungan anak yang pada pokoknya bertujuan untuk memberikan jaminan dan melindungi hak-haknya agar dapat hidup, tumbuh, berkembang dan berpartisipasi, secara optimal, serta memperoleh perlindungan dari kekerasan dan diskriminasi (Muhadar, 2009: 74).

Demikian pula dalam UndangUndang No. 3 tahun 1997 Perubahan Atas Undang-Undang Nomor 11 Tahun 2012 tentang Sistem Peradilan Pidana Anak. Di dalam Undang-Undang tersebut yakni pada Pasal 6 sampai dengan Pasal 15 terdapat diversi. Diversi merupakan pembaharuan dalam sistem peradilan pidana anak. Pengalihan perkara (diversi) yang dilakukan yaitu pengalihan yang semula jatuh kepada proses peradilan sehingga beralih kepada bantuan hukum untuk pelayanan masyarakat pencari keadilan diterapkan pada dasar formal dan informal. Kemudian secara pelaksanaan yang demikian itu diperlukan untuk mengubah dampak negatif yang timbul secara administrasi pada peradilan anak. Hal ini dilakukan berguna sebagai alternatif penyelesaian perkara anak, khususnya anak yang berhadapan dengan hukum. Karena dengan melibatkan anak dalam suatu proses peradilan memberikan label negatif pada anak, sehingga akan merusak mental dan fikiran anak. Dengan demikian pengalihan dilaksanakan pada setiap tingkat pembuat keputusan baik pada tingkat, polisi, penuntut maupun pada tingkat pengadilan (Priyatno Dwidja, 2012: 303).
Pelaksanaan diversi oleh aparat penegak hukum di dasari oleh kewenangan aparat hukum yang disebut discretion atau diskresi (Marlina, 2010: 71). Diskresi adalah wewenang dari aparat penegak hukum yang menangani kasus tindak pidana untuk mengambil tindakan meneruskan atau menghentikan perkara, mengambil tindakan tertentu sesuai kebijakan (Marlina, 2010: 72).

Kepolisian saat ini menjadi pintu utama sebagai garda terdepan masuknya berbagai jenis perkara dalam hal ini lebih spesifiknya perkara pidana. Peranan pihak kepolisian dalam melihat melalui kacamata tugasnya sebagai institusi Kebijakan petugas polisi suatu kasus pidana yang mana anak sebagai pelaku, di sini pihak kepolisian akan menentukan tindakan apa yang akan dilakukan terhadap si anak. Pihak kepolisian memegang peran utama dalam menentukan suatu perkara, karena peran kepolisian memang sangat strategis dalam pelaksanaan wewenang diskresi dalam melakukan diversi pada kasus anak, hal ini terlihat dalam Undang-Undang Kepolisian memberikan wewenang secara tertulis kepada polisi untuk melakukan diskresi, namun ini dalam arti lain bukan berarti aparat penegak hukum lainnya tidak mempunyai kewenangan dalam melakukan proses diversi ini yang terkhusus terhadap anak sebagai pelaku tindak pidana.

Kewajiban bagi aparat penegak hukum untuk mengupayakan diversi tanpa terkecuali bagi pihak Kepolisian Polres Sijunjung. Menurut Pasal 1 Ayat (1) 
Undang-undang No. 11 tahun 2012 diversi adalah pengalihan perkara anak dari proses peradilan pidana ke proses luar peradilan pidana. bila dilihat dari pasal-pasal yang mengatur tentang diversi yakni mulai dari Pasal 6 sampai dengan Pasal 15 di dalam Undang-Undang Nomor 11 Tahun 2012 tentang Sistem Peradilan Pidana Anak, tidak ada satupun pasal yang secara tegas mengatur tentang perlindungan terhadap korban, hak-hak korban, maupun kepentingan korban.

\section{METODE PENELITIAN}

Jenis penelitian yang digunakan dalam melakukan penelitian ini adalah yuridis sosiologis (empiris) untuk membahas dan menjawab pertanyaan yang telah dirumuskan dalam rumusan masalah artinya suatu penelitian yang dilakukan terhadap keadaan nyata masyarakat atau lingkungan masyarakat dengan maksud dan tujuan guna menemukan fakta-fakta yang ada kemudian merujuk pada pengidentifikasian permasalahan. Sifat penelitian yang digunakan dalam penelitian ini adalah deskriptif analitis yakni penelitian dapat mencapai tujuan dengan memberikan gambaran secara menyeluruh tentang perkara anak yang berhadapan dengan hukum di Polres Sijunjung. Melalui penelitian yuridis empiris, dapat terlihat bagaimana proses penyelesaian perkara anak yang berhadapan dengan hukum melalui jalur mediasi dengan diversi dilakukan diluar jalur peradilan dengan pendekatan restroaktif di wilayah Sijunjung. Namun sebelum Pelaksanaannya penegak hukum yang di sini polisi sebagai garda terdepan harus betul-betul memahami bagai pelaksanaan konsep diversi. Sedangkan untuk mengetahui pelaksanaannya itu sendiri, digunakan metode penelitian yang bersifat kualitatif.

\section{HASIL DAN PEMBAHASAN}

\section{Pelaksanaan Diversi Sebagai Alternatif Penyelesaian Perkara Terhadap Anak Yang Berhadapan Dengan Hukum}

Pentingnya pelaksanaan diversi kepada anak sebagai altenatif penyelesaian perkara anak yang berhadapan dengan hukum. Sehingga menjadi kewajiban para penegak hukum untuk melanjutkan proses diversi apabila memenuhi unsur dan kategori yang mana ancaman hukuman tidak melebihi dari 7 (tujuh) tahun sesuai dengan ketentuan hukum yang ada.. Hal ini menjadi wajib dilakukan karena berkaitan dengan kepentingan Hak asasi manusia guna membela kepentingan anak, meskipun anak tersebut sebagai pelaku dari suatu tindak pidana.

Berlakunya Undang-undang Nomor 3 Tahun 1997 Tentang Pengadilan Anak dilihat memang sudah tidak sesuai lagi dengan perkembangan dan tuntutan pada saat sekarang ini. Karena dianggap tidak secara keseluruhan melindungi kepentingan anak yang berhadapan dengan hukum $(\mathrm{ABH})$. Disebabkan oleh berubah dan berkembangnya pola penanganan terhadap anak yang berhadapan dengan hukum maupun anak sebagai korban. 
Sry Wahyuni dan Helfira Citra: Pelaksanaan Diversi Dalam Penyelesaian Perkara Anak...

Maka dari itu perlunya perubahan pola pemikiran yang saling bersinergi antara masing-masing pihak, baik pemerintah, masyarakat, lembagalembaga terkait lainnya, serta peran orang tua sangat diperlukan karena itu merupakan tugas bersama yang menjadi kewajiban dan tanggungjawab untuk memikirkan mengenai perlindungan khusus terhadap anak yang berhadapan dengan hukum. Bagaimanapun anak yang berhadapan dengan hukum tetaplah anak yang harus dilindungi sekalipun sudah melakukan kejahatan. Oleh karena itu berkaitan dengan semua prosedur dan tata cara Diversi diatur dalam UndangUndang Perlindungan anak Nomor 11 Tahun 2012 perubahan atas Undangundang Nomor 3 tahun 1997.

Aturan terbaru tersebut lebih lengkap dan terperinci sebagaimana dinyatakan dalam Pasal 8 bahwa proses diversi dilakukan melalui musyawarah dengan melibatkan anak dan orang tua/walinya, korban dan/atau orang tua/walinya, pembimbing kemasyarakatan, Pekerja Sosial. Sebagaimana yang telah penulis teliti secara langsung Di Polres Sijunjung yang mana menurut Pasal 29 Undangundang No.11 Tahun 2012 setiap perkara anak yang masuk ke Polres Sijunjung penyidik wajib melakukan Diversi dalam kurun waktu paling lama tujuh hari setelah dimulainya penyidikan (wawancara dengan bripda Nina, 2018: Mei) Proses Diversi itu paling lama jangka waktunya selama tiga puluh hari semenjak dimulainya proses Diversi terhadap kasus anak. Sebagaimana tertera dalam ayat (3) apabila proses diversi mencapai suatu kesepakatan, maka pihak penyidik Polres Sijunjung menyampaikan berita acara diversi untuk dibuat penetapan.

Dalam ayat (4) Pasal 29 dalam hal Diversi gagal, maka penyidik wajib melanjutkan penyidikan dan melimpahkan perkara ke Penuntut Umum dengan melampirkan berita acara diversi dan laporan Penelitian Kemasyarakatan. Maka dalam Pasal 29 ayat (4) penjelasannya bahwa agar pemeriksaan pada tahap selanjutnya mengetahui ada tindakan upaya diversi dan sebab gagalnya diversi. Jelas di sini terlihat bahwa proses diversi sangat penting dilakukan guna mempertahankan hak-hak anak yang berhadapan dengan hukum.

Pada pasal 96 Undang-Undang No 11 Tahun 2012 Tentang Sistem Peradilan Pidana Anak di dalamnya menyatakan bahwa penyidik, Penuntut Umum, dan Hakim yang dengan sengaja tidak melaksanakan kewajiban sebagaimana dimaksud dalam Pasal 7 ayat (1) di Pidana dengan pidana penjara paling lama 2 (dua) tahun (Pasal 96 Undang-undnag No 11 Tahun 2012 Tentang Sistim Peradilan Anak). Dalam Undang-Undang ini kehadiran orang tua/wali dari pihak korban wajib dihadirkan dalam proses diversi apabila korban yang dimaksud adalah anak. Proses musyawarah selama berlangsungnya diversi jika diperlukan juga melibatkan Pekerja Sosial, dan apabila si anak masih bersekolah dapat juga menghadirkan guru Bimbingan Konseling (BK), dan tokoh masyarakat 
ditempat anak yang berhadapan dengan hukum tinggal seperti ketua RT atau Lurah setempat. Pentingnya memperhatikan setiap proses diversi yang dilaksanakan karena harus memperhatikan kepentingan korban dan tanggung jawab anak, untuk menghindari penilaian negatif dari lingkungan, untuk menghindari tindakan balasan, bulying, serta keharmonisan masyarakat terhadap keputusan diversi dan kepentingan umum.

Selanjutnya diatur pula aspek prosedural dan tata cara diversi lainnya dalam Pasal Ayat (1) dan ayat (2) yaitu:

1. Penyidik, Penuntut Umum dan Hakim dalam melakukan diversi harus mempertimbangkan:
a. Kategori tindak pidana;
b. Umur anak;
c. Hasil penelitian kemasyarakatan dari Bapas, dan
d. Dukungan dari lingkungan keluarga dan masyarakat.

2. Kesepakatan diversi harus mendapatkan persetujuan korban dan/atau keluarga Anak korban serta kesediaan anak dan keluarga, Kecuali untuk:
a. Tindak pidana yang berupa pelanggaran;
b. Tindak pidana ringan
c. Tindak pidana tanpa korban
d. Nilai kerugian korban tidak melebihi nilai upah minimum provinsi setempat.

Prosedur dan tata cara pelaksanaan lainnya juga diatur dalam Pasal 10 Undang-Undang No 11 Tahun 2012 Tentang Sistem Peradilan Pidana Anak, pada Ayat (1) bahwa prosedur selanjutnya kesepakatan diversi untuk menyelesaikan tindak pidana yang berupa pelanggaran, tindak pidana ringan, tindak pidana tanpa korban, atau nilai kerugian korban tidak lebih dari upah minimum Provinsi setempat dan juga dijelaskan dalam Pasal 9 Ayat (2) dapat dilakukan oleh penyidik bersama pelaku dan/atau keluarganya, Pembimbing Kemasyarakatan, serta dapat melibatkan tokoh Masyarakat.

Berikutnya dalam Ayat

dikemukakan bahwa kesepakatan diversi sebagaimana dimaksud pada Ayat (1) dilakukan oleh penyidik atas rekomendasi Pembimbing Kemasyarakatan dapat dalam bentuk:

a. Pengembalian kerugian dalam hal ada korban;

b. Rehabilitasi medis dan Psikososial;

c. Penyerahan kembali kepada orang tua/wali;

d. Keikutsertaan dalam pendidikan atau pelatihan di lembaga pendidikan atau LPKS paling lama tiga bulan.

Pasal 11 Undang-Undang No 11 Tahun 2012 tentang Sistem Peradilan Pidana Anak dapat dilihat bentuk kesepakatan diversi antara lain;

a. Perdamaian dengan atau tanpa ganti kerugian;

b. Penyerahan kembali kepada orang tua/wali

c. Keikutsertaan dalam pendidikan atau pelatihan di lembaga pendidikan atau LPKS paling lama tiga bulan; atau

d. Pelayanan masyarakat.

Aturan lainnya menyangkut hal diatas juga terdapat dalam Pasal 12 Ayat (1) yakni hasil kesepakatan sebagaimana dimaksud dalam Pasal 11 dituangkan dalam bentuk kesepakatan diversi. (2) hasil kesepakatan diversi sebagaimana dimaksud pada Ayat (1) disampaikan 
Sry Wahyuni dan Helfira Citra: Pelaksanaan Diversi Dalam Penyelesaian Perkara Anak...

kepada oleh atasan langsung pejabat yang bertanggung jawab pada setiap tingkatan pemeriksaan ke pengadilan negeri sesuai dengan daerah hukumnya dalam waktu paling lama tiga hari semenjak kesepakatan tercapai untuk memperoleh penetapan. (3) penetapan sebagaimana dimaksud ayat (2) dilakukan dalam kurun waktu paling lama tiga hari terhitung semenjak diterimanya kesepakatan diversi. (4) penetapan sebagaimana dimaksud pada ayat (3) disampaikan kepada pembimbing kemasyarakatan, penyidik, Penuntut Umum dan Hakim dalam waktu paling lama tiga hari sejak ditetapkan. (5) setelah menerima penetapan sebagaimana dimaksud pada ayat (4), penyidik menerbitkan penetapan penghentian penyidikan atau penuntut umum menerbitkan penetapan penghentian penuntutan. (Psal 11 dan Pasal 12 Undang-undang No. 11 Tentang Sistem Peradilan Pidana).

Adapun aturan tambahan yang memperkuat mengenai diversi ini yaitu Peraturan Pemerintah Nomor 65 Tahun 2015 menyatakan bahwa yang pertama hasil kesepakatan diversi dituangkan dalam bentuk Surat Kesepakatan diversi. Kedua adalah hasil kesepakatan sebagaimana dimaksud diatas harus ditetapkan oleh Ketua Pengadilan Negeri di Wilayah tempat terjadinya perkara atau di wilayah tempat kesepakatan diversi dibuat dalam hal ini peneliti meneliti di Polres Sijunjung yang sebagian berada di Wilayah Hukum Pengadilan Negeri Sawahlunto.

\section{Bentuk Diversi Sebagai Mediasi Penal Yang Diterapkan Polres Sijunjung}

Sebelum beranjak pada pembahasan bentuk diversi sebagai mediasi penal yang diterapkan Polres Sijunjung penulis akan berbicara sedikit mengenai penyidikan yang dilakukan oleh Unit Pelayanan Perempuan dan Anak (PPA) Polres Sijunjung terhadap tindak pidana yang dilakukan oleh anak. Penyidikan kasus pidana yang dilakukan oleh anggota kepolisian khususnya Unit Pelayanan Perempuan dan Anak (PPA) sudah sesuai dengan Hukum Acara Pidana terutama Khusus terhadap penyidikan dan penyelidikan terhadap anak pelaku tindak pidana atau anak yang berhadapan dengan hukum lebih jelas di atur dalam UndangUndang nomor 11 Tahun 2012 Tentang Sistem Peradilan Pidana Anak, serta Undang-Undang Nomor 35 Tahun 2014 Tentang Perubahan Atas Undang-Undang Nomor 23 Tahun 2002 Tentang Perlindungan Anak. Pihak kepolisian khususnya bertugas untuk melakukan penyidikan dan penyelidikan di Polres Sijunjung sudah berpedoman pada ketentuan peraturan yang ada untuk kasus yang dilakukan oleh anak sebagai pelaku.

Diversi yang dilaksanakan dengan menghadirkan pelaku, keluarga pelaku, korban, keluarga korban, pembimbing kemasyarakatan (BAPAS), pekerja sosial (PEKSOS), tokoh masyarakat seperti ketua RT atau lurah setempat, pelaku yang masih bersekolah maka turut dihadirkan juga kepala sekolah ataupun guru bimbingan Konseling (BK). 
Sebelum dilaksanakannya diversi maka terlebih dahulu pihak penyidik melakukan wawancara dengan anak pelaku untuk mengetahui dan mendapatkan keterangan mengenai motif kejahatan yang dilakukan sehingga penyidik bisa memahami apa yang terjadi dan mempermudah untuk dilaksanakannya proses tahapan diversi guna mencapai kesepakatan.

Selanjutnya keputusan diversi harus merujuk pada hasil mediasi atau musyawarah yang di ambil pada saat proses bersama karena ada pengecualian terhadap beberapa kasus anak yang berhadapan dengan hukum diversi tidak dapat dilanjutkan. Ada beberapa yang mensyaratkan untuk dilaksanakannya proses diversi yakni tindak pidana yang dilakukan dengan ancaman pidana dibawah 7 (tujuh tahun) dan perbuatan tersebut bukan merupakan perbuatan pengulangan tindak pidana.

Hasil yang penulis dapatkan dari wawancara pada bulan Mei 2018 dengan penyidik PPA di Polres Sijunjung, dalam menangani kasus anak yang berhadapan dengan hukum dilaksanakan atau tidaknya diversi bergantung pada kriteria tindak kejahatan yang dilakukan dan hasil dari kesepakatan bersama. Tidak semua jenis tindak pidana yang telah dilakukan oleh anak itu bisa dilakukan atau dilaksanakannya proses diversi karena ada beberapa kriteria yang sudah dijelaskan dalam undang-undang pada penjelasan awal. Kemudian keputusan diversi itu memang harus mendapatkan persetujuan dari pihak korban dan keluarganya. Sebagaimana yang diatur dalam Undang-
Undang No 11 Tahun 2012 Pasal 11 tentang bentuk kesepakatan Diversi, yaitu:

a. Perdamaian dengan atau tanpa ganti kerugian;

b. Penyerahan kembali kepada orang tua/Wali

c. Keikutsertaan dalam pendidikan atau pelatihan di Lembaga pendidikan, atau LPKS paling lama 3 (tiga) bulan; atau

d. Pelayanan masyarakat.

Merujuk dari aturan tersebut maka pihak penyidik PPA Polres Sijunjung yang telah melakukan mediasi melalui permusyawaratan, bentuk diversi yang dilakukan dari hasil kesepakatan bersama dari pihak korban, keluarga korban, pelaku, keluarga pelaku, pihak terkait dengan permasalahan diversi anak. Berupa kesepakatan perdamaian dengan persyaratan tertentu misalnya ganti kerugian yang sesuai dengan nilai minimum porvinsi setempat, dalam hal ini apabila korban mengalami luka-luka maka hasil dari kesepakatan diversi menuntut pelaku membiayai biaya pengobatan korban sampai pulih.

Selanjutnya bentuk mediasi penal yang diterapkan oleh Polres Sijunjung hasil dari kesepakatan bersama yaitu Sholat Lima waktu (Subuh, Zuhur, Ashar, Magrib, Isya) harus dilaksanakan di mesjid serta berkewajiban membersihkan mesjid, yang mana mesjid yang dipilih sesuai dengan domisili pelaku dan diawasi oleh pihak terkait seperti ketua RT sebagai pemantau. Selain itu apabila anak pelaku sudah tidak dapat dibina dan orang tua pelaku sudah tidak sanggup lagi 
Sry Wahyuni dan Helfira Citra: Pelaksanaan Diversi Dalam Penyelesaian Perkara Anak...

untuk mendidik maka diserahkan kepada pihak BAPAS untuk diserahkan ke balai Pelatihan kerja PSAABR yang berada di wilayah Pariaman selamat 3 (tiga) bulan kemudian pihak penyidik PPA Polres Sijunjung yang nantinya mengantar anak pelaku ke balai pelatihan tersebut.

Tabel 1 jumlah kasus yang berhasil dilaksanakan proses diversi dari tahun 2014 - 2018

\begin{tabular}{llllll}
\hline No & Tahun & JK & D & TD & Ket \\
\hline 1 & 2014 & 3 & - & 3 & \\
2 & 2015 & 8 & 3 & 4 & \\
3 & 2016 & 7 & 3 & 4 & \\
4 & 2017 & 18 & 18 & 18 & \\
5 & 2018 & 12 & 8 & 4 & Mei 2018 \\
\hline
\end{tabular}

Ket: JK (Jumlah Kasus), D (Diversi), TD (Tidak Bisa Terlaksana Diversi), Ket (Keteranan)

Sumber: PPA Polres Sijunjung

Berdasarkan Tabel tersebut dari aspek hasil kesepakatan diversi di tingkat penyidikan yang berhasil dilaksanakan dari tahun 2014 sampai dengan bulan Mei tahun 2018 ini dibandingkan dengan yang tidak bisa dilaksanakan diversi perubahan dari tahun ke tahun hampir mencapai keseluruhan. Dari kasus pidana yang dilakukan oleh anak yang telah mencapai kesepakatan diversi dan damai dengan persyaratan dan telah melaksanakan hukuman kesepakatan bersama berguna untuk si anak tersebut tindakan mengulangi perbuatan yang telah dilakukan dan juga sebagai peringatan.

Lain halnya dengan diversi yang gagal dilaksanakan dalam mencapai kata sepakat, disebabkan terutama keluarga/korban tidak terima/tidak sepakat dengan adanya perdamaian. Pihak korban cenderung ingin kasus ini lanjut sampai ke tingkat yang lebih tinggi agar pelaku bisa dipenjara. Semenjak diberlakukannya Undang-undang No 11 Tahun 2012 Tentang Peradilan Pidana Anak dan Undang-undang No 35 Tahun 2014 Tentang Perlindungan Anak dari tabel tersebut bisa terlihat dari tahun 2014 sampai dengan Mei 2018 usaha yang dilakukan oleh pihak Polres Sijunjung sudah maksimal, proses diversi sudah berjalan dengan baik sesuai dengan prosedur dan ketentuan sebagaimana yang telah diatur oleh Undang-undang.

\section{Kendala-Kendala Yang Dihadapi Dalam Pelaksanaan Diversi Sebagai Alternatif Penyelesaian Perkara Terhadap Anak Yang Berhadapan Dengan Hukum Di Polres Sijunjung}

1) Mengumpulkan pihak-pihak yang terkait dalam proses Diversi

Dalam mengumpulkan pihak-pihak terkait seperti pelaku, keluarga pelaku, korban, keluarga korban serta pihak terkait lainnya yang sulit untuk bertemu dan melaksanakan proses Diversi. Dikarenakan enggan untuk datang ke Polres Sijunjung karena kesibukan dan tidak adanya koordinasi diantara pihak terkait yang berhubungan pelaksanaan proses diversi.

Selanjutnya orang tua pelaku yang berkeberatan datang dalam proses diversi lebih kepada malu terhadap masyarakat, dikarenakan anaknya sudah melakukan suatu tindak pidana. Beranggapan bahwa pihak Polres Sijunjung dan BAPAS sudah mewakilinya. 
2) Sulit mencapai kata sepakat dalam perdamaian

Sulitnya mencapai kata sepakat dalam proses pelaksanaan diversi ini karena pihak dari korban/keluarga yang tidak sepakat dengan perdamaian, dan juga korban atau keluarga ingin agar pelaku di penjara tanpa memikirkan dampak bagi anak tersebut. Jadi seakanakan ingin membalaskan dendam apa yang telah diperbuat oleh pelaku terhadap anaknya.

Lainnya halnya dengan kesepakatan ganti kerugian yang gagal, penyebabnya permintaan atas ganti kerugian oleh pihak korban terlalu tinggi ataupun melebihi batas minimum upah provinsi. Pelaku/keluarga pelaku berkeberatan untuk melaksanakan kesepakatan bersama karena dinilai tidak masuk akal atas permintaan dari keluarga korban keputusan damai dengan persyaratan tertentu.

3) Keputusan damai dengan persyaratan tertentu

Kendala terakhir yang dihadapi oleh Polres Sijunjung dalam hal pelaksanaan diversi keputusan damai dengan persyaratan tertentu, kemungkinan diversi itu tidak berhasil adalah apabila antara kedua belah pihak terutama pihak korban menyatakan perdamaian bisa dicapai jika semua syarat terpenuhi. Syarat yang ditentukan yang dapat dijalani apabila si anak sanggup menjalankan tanpa menghilangkan hak-hak anak itu sendiri, bagaimanapun pelaku tetaplah dipandang sebagai anak yang mana hak-haknya wajib dilindungi.

Persyaratan diversi yang terlalu berat atau syarat yang diajukan sudah tidak sesuai dengan peraturan atau aturan. maka di situlah terdapat kendala dan kesepakatan bersama tidak bisa diwujudkan.

\section{SIMPULAN}

Berdasarkan hasil penelitian dari pembahasan yang telah kemukakan diatas, maka dapat disimpulkan sebagai berikut: Pertama, Proses diversi yang dilaksanakan harus berdasarkan peraturan perUndang-Undangan Nomor 11 Tahun 2012, maka pihak kepolisian dalam hal ini penyidik wajib melaksanakan proses diversi dalam kurun waktu tujuh hari setelah penyidikan dimulai, dengan melibatkan pihak yang terkait dalam proses diversi. Kedua, Bentuk diversi sebagai mediasi penal yang diterapkan Polres Sijunjung, berupa hasil dari kesepakatan dari hasil musyawarah bersama pihak terkait, apabila terjadi kesepakatan maka hukuman bisa segera dilaksanakan seperti kegiatan rutin solat di masjid lima waktu serta membersihkan masjid setempat, serta ganti kerugian dalam hal pengobatan korban sampai sembuh, dan bentuk lainnya yang diterapkan sesuai dengan hasil musyawarah. Ketiga, kendala-kendala yang dihadapi dalam pelaksanaan diversi sebagai alternatif penyelesaian perkara terhadap anak yang berhadapan dengan hukum di Polres Sijunjung adalah dalam mencapai kata sepakat atau selama proses diversi itu berlangsung, yang pertama itu 
Sry Wahyuni dan Helfira Citra: Pelaksanaan Diversi Dalam Penyelesaian Perkara Anak...

sulitnya mengumpulkan pihak-pihak yang terkait dalam diversi ini, selanjutnya sulitnya mencapai kata sepakat atau perdamaian kedua belah pihak dan keputusan damai dengan persyaratan tertentu yang tidak memungkin dijalani.

\section{UCAPAN TERIMAKASIH}

Alhamdulillahhirabbilalamin, banyak nikmat yang Allah berikan, tetapi sedikit sekali yang kita ingat. Segala puji hanya layak untuk Allah atas segala Berkat, rahmat, taufik, serta hidayah-Nya yang tiada terkira besarnya, sehingga saya dapat menyelesaikan laporan akhir penelitian ini. Serta salawat beriring salam kepada Nabi Besar muhammad SAW atas pencerahan iman yang diberikan kepada kita semua. Penulisan laporan akhir penelitian ini dapat terwujud dengan dukungan dan peranan dari berbagai pihak. Untuk itu penulis mengucapkan terima kasih yang sebesarbesarnya kepada semua pihak yang telah membantu dalam penulisan laporan akhir penelitian ini. Penulisan ucapkan terima kasih kepada:

Bapak Kapolres Sijunjung dan Penyidik Pelayan Perempuan dan Anak serta Kemenristekdikti yang telah mendanai Penelitian Dosen Pemula.

Dalam penulisan hasil penelitian ini penulis menyadari bahwa masih banyak kekurangan, hal ini dikarenakan keterbatasan ilmu pengetahuan yang penulis miliki. Penulis mengharapkan kritikan dan saran yang membangun di masa yang akan datang. Penulis Berharap hasil penelitian ini bisa digunakan oleh semua orang terutama bagi penulis sendiri sebagai acuan ataupun pedoman terhadap masalah yang berhadapan dengan hukum. Dengan ini penulis mengucapkan maaf apabila ada salah dalam penulisan. Pengakhir kata penulis mengucapkan banyak terima kasih atas semangat dan bimbingan selama ini dan dibalas pahala Oleh Allah

\section{DAFTAR PUSTAKA}

Nandang Sambas, 2010, Pembaharuan Sistem Pemidanaan Anak di Indonesia, Graha Ilmu, Yogyakarta.

Setya Wahyudi, 2010, Implementasi Ide Diversi dalam Pembaharuan Sistem Peradilan Pidana Anak di Indonesia, Genta Publishing, Yogyakarta.

Muhadar, Abdullah, Husni Thamrin, 2009, Perlindungan Saksi dan Korban dalam Sistem Peradilan Pidana, CV Putra Media Nusantara, Surabaya.

Dwidja Priyatno, 2012, Wajah Hukum Pidana Asas dan Perkembangan, Gramata Publishing, Bekasi.

Marlina, 2010, Pengantar Konsep Diversi dan Restorative Justice Dalam Hukum Pidana, USU Press, Medan.

Marlina, 2008, Penerapan Konsep Diversi Terhadap Anak Pelaku Tindak Pidana dalam Sistem Peradilan Pidana Anak. Jurnal Equality. Vol. 13. No.1 Februari.

Undang-Undang Perlindungan Nomor 35 Tahun 2014 Tentang Perlindungan Anak 
Jurnal Cendekia Hukum: Vol. 4, No 1, September 2018

Undang-Undang Nomor 22 Tahun 2002

Tentang Kepolisian Negara

Republik Indonesia
Undang-Undang Nomor 11 Tahun 2012

Tentang Sistem Peradilan Anak. 